\title{
Editorial
}

\section{Tecnologia é atemporal, só precisa ser bem usada}

$\mathrm{D}$ e diferentes modos, o estudo do plasma ainda é uma das ciências mais abrangentes entre aquelas baseadas na tecnologia de vácuo; portanto não é surpreendente que Sant'Ana et al. tenham encontrado tantas aplicações para o plasma. Também não é incomum a declaração de que a "fronteira final" foi atingida. Ocorreu com o desenvolvimento de vários dispositivos semicondutores, como as células solares, duas décadas atrás, devido aos substratos flexíveis' ${ }^{1}$, pela necessidade da nanoeletrônica de ultrapassar as barreiras da lei de Moore uma década atrás ${ }^{2}$, o que também levou à ciência dos novos materiais ${ }^{3}$ e, como consequência, à pesquisa de novos dispositivos, o que fez Thomas Heine declarar que, devido à óptica e à fotônica, "existe uma lei de Moore para os lasers, pelo escalamento no aumento da potência de saída e pela redução de custos"4. Assim, um ciclo virtuoso de desenvolvimento é completado com uma nova lei de Moore em jogo e a "fronteira final" redefinida.

Todas essas fronteiras foram amplamente expandidas graças à ciência de plasma e ao desenvolvimento de novos materiais. Quanto aos novos materiais, três trabalhos admiráveis atuando com a corrosão de modos bem distintos são apresentados. Santos et al. propõem como atuar simultaneamente com plasma gasoso e o processamento em líquido; Almeida et al. apresentam a modificação superficial com carbono tipo diamante (DLC, do inglês diamond-like carbon) para proteção de titânio contra desgaste, de modo similar ao que Santos et al. fizeram para Inconel.

Além disso, nosso parceiro CIMATech ${ }^{5}$ nos brindou com modos altamente tecnológicos e elegantes de manufatura, por exemplo, para aviônica. Ao fim e ao cabo, tudo isso baseado na tecnologia de vácuo!

\section{Technology is timeless, it just needs to be well used}

$\mathrm{n}$ different ways, plasma is still one of the most comprehensive sciences among those based on vacuum technology; so, it is not surprising that Sant'Ana et al. have found so many applications for it. Neither is it unusual to state that the "final frontier" has been

reached. This occurred with the development of various semiconductor devices, such as solar cells, two decades ago, due to flexible substrates $^{1}$, the need for nanoelectronics to break through the barriers of Moore's law a decade ago ${ }^{2}$, which also led to the science of new materials ${ }^{3}$ and, consequently, to the research of new devices, which, due to optics and photonics, made Thomas Heine to declare

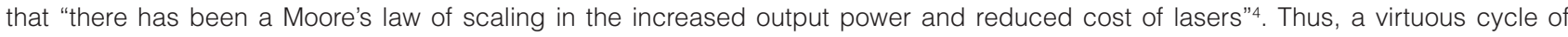
development is completed with a new Moore law at stake and the "final frontiers" redefined.

Notwithstanding, all these frontiers have been widely expanded because of plasma science and the development of new materials. Regarding new materials, three admirable studies working with corrosion in very different ways are presented. Santos et al. propose how to act simultaneously with gaseous plasma and processing in liquid; Almeida et al. present the surface modification with DLC for protection of titanium against wear, in a similar way to what Santos et al. did for Inconel.

Last but not least, our partner CIMATech ${ }^{5}$ has provided us with highly technological and elegant manufacturing modes, for instance, in avionics. At the very end, all this based on vacuum technology!

1. Yang J, Banerjee A, Guha S. Amorphous silicon based photovoltaics - from earth to the "final frontier". Sol Energy Mater Sol Cells. 2003;78(14):597-612. https://doi.org/10.1016/S0927-0248(02)00453-1

2. Meindl J, Naeemi A, Bakir M, Murali R. Nanoelectronics in retrospect, prospect and principle. In: 2010 IEEE International Solid-State Circuits Conference - (ISSCC). São Francisco: IEEE; 2010. https://doi.org/10.1109/ISSCC.2010.5434062

3. Heine T. Grand challenges in computational materials science: from description to prediction at all scales. Front Mater. 2014;1:7. https://doi. org/10.3389/fmats.2014.00007

4. Graydon O. Conquering the final frontier. Nature Photon. 2018;12:647-48. https://doi.org/10.1038/s41566-018-0289-y

5. Fatec São José dos Campos. VI CIMATech [Internet]; 2019 Out. 22-24. São José dos Campos: Fatec; 2019. [acesso em 5 Mai 2020]. Disponível em: http://www.cimatech.com.br/ 